\title{
Quality management in imaging diagnosis and the nursing team: a case study
}

\author{
Gestão da qualidade em diagnóstico por imagem e a equipe de enfermagem: estudo de caso \\ Gestión de calidad del diagnostico por imagen y el equipo de enfermería:estúdio de caso
}

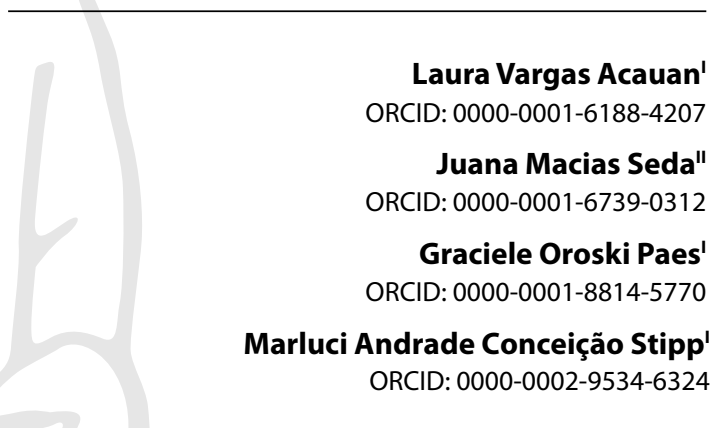

'Universidade Federal do Rio de Janeiro. Rio de Janeiro, Rio de Janeiro, Brazil.

"Universidad de Sevilla, Facultad de Enfermería, Fisioterapia y Podología. Sevilha, Andaluzia, Espanha.

How to cite this article: Acauan LV, Macias-Seda J, Paes GO, Stipp MAC. Quality management in imaging diagnosis and the nursing team: a case study. Rev Bras Enferm. 2021;74(Suppl 5):e20200912. https://doi.org/10.1590/0034-7167-2020-0912

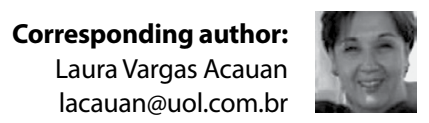

EDITOR IN CHIEF: Antonio José De Almeida Filho ASSOCIATE EDITOR: Mitzy Reichembach

Submission: $08-24-2020$

Approval: $11-12-2020$

\section{ABSTRACT}

Objective: to know the contributions of nursing in the implementation of the quality management principle of the accreditation program in imaging diagnosis. Methods: a single, qualitative case study carried out in an accredited radiology and imaging diagnosis service. The data collection took place through semi-structured interviews, direct observation, and documentary analysis with the support of software in organizing the data for analysis. Results: a total of four thematic units emerged: the accreditation process in imaging services, the implementation of the program, the role of nursing in imaging services and patient safety and the management of non-conformities in imaging services. Of the other data sources, the word risk was highlighted and a non-conformity was evidenced in the external audit. Final considerations: nursing contributed mainly to the management of the risks involved in the performance of imaging and patient safety tests, requirements of the quality management principle of the accreditation program.

Descriptors: Accreditation of Health Institutions; Quality Management; Imaging Diagnosis; Patient Safety; Nursing Team.

\section{RESUMO}

Objetivo: conhecer as contribuições da enfermagem na implementação do princípio gestão da qualidade do programa de acreditação em diagnóstico por imagem Métodos: estudo de caso único, qualitativo, realizado num serviço de radiologia e diagnóstico por imagem acreditado. A coleta se deu através de entrevista semiestruturada, observação direta e análise documental com apoio de software na organização dos dados para análise. Resultados: obteve-se quatro classes temáticas: o processo de acreditação nos serviços de imagem, a implementação do programa, o papel da enfermagem nos serviços de imagem e na segurança do paciente e a gestão de não conformidades nos serviços de imagem. Das demais fontes de dados, destacou-se a palavra risco e foi evidenciada uma não conformidade na auditoria externa. Considerações finais: a enfermagem contribuiu principalmente na gestão dos riscos envolvidos na realização dos exames de imagem e segurança do paciente requisitos do princípio gestão da qualidade do programa de acreditação.

Descritores: Acreditação de Instituições de Saúde; Gestão da Qualidade; Diagnóstico por Imagem; Segurança do Paciente; Equipe de Enfermagem.

\section{RESUMEN}

Objetivo: conocer los aportes de la enfermería en la implementación del principio de gestión de calidad del programa de acreditación del diagnóstico por imagen. Métodos: estudio de caso único, cualitativo, en servicio acreditado de radiología e imagen diagnóstica. La recolección se realizó a través de entrevistas semiestructuradas, observación directa y análisis documental con apoyo de software para el análisis. Resultados: se obtuvieron cuatro clases temáticas: el proceso de acreditación en los servicios de imagenología, la implementación del programa, el rol de la enfermería en los servicios de imagenología y seguridad del paciente y la gestión de no conformidades en los servicios de imagenología. De los otros datos, se destacó la palabra riesgo y se detectó una no conformidad en la auditoría externa. Consideraciones finales: la enfermería contribuyó principalmente en la gestión de los riesgos involucrados en los exámenes de imagen y la seguridad del paciente, requisitos del programa de acreditación.

Descriptores: Acreditación de Instituciones de Salud; Gestión de Calidad; Diagnóstico por Imagen; Seguridad del Paciente; Plantel de Enfermería. 


\section{INTRODUCTION}

Quality management in the context of radiology and imaging diagnosis services (RIDS) refers to the understanding of the importance of quality as a determining factor in competitiveness due to several factors such as globalization, technological evolution, increased competition, changes in the profile of patients in these services. Like any health service, it is an open system and also suffers the action of the environment that constantly changes, at the same time that it contributed to the emergence of a new way of seeing its internal and external relations to meet new demands of imaging services ${ }^{(1-2)}$.

Thus, the search for quality in the services that occupy an important place in health care has evolved along with technological progress and has expanded, characterizing a current movement in this health market that is imbued to seek excellence and sustainable development with focus on management, quality of exams, reports and patient safety ${ }^{(3-4)}$.

Quality as a management function in imaging services shows visible growth and development, aiming at meeting the demands of an aging population, an increase in chronic degenerative diseases, with relevance in the detection and early screening of diseases for the selection of the ideal therapy. Among other reasons, these services have become a differential and their evaluation, a reliability certification ${ }^{(2,4)}$.

In line with this finding, in 2015 the Brazilian School of Radiology and Imaging diagnosis (BSR) created the Accreditation Program in Imaging Diagnosis (Apid) to assess the quality of imaging services. The Program was accredited in January 2017 by the International Society for Quality in Healthcare (ISQua), which strengthened its relevance and alignment with the evolution of the health market, seeking quality, safety and sustainability of these services ${ }^{(1)}$.

It is a voluntary program, applicable to public, private and philanthropic services in Brazil, serving any size of service, regardless of the number of employees, available tests and number of exams performed, satisfying confidentiality criteria. It is free available on the BSR website, and evaluates images and reports of all examination methods performed by the service, in addition to evaluating all stages that involve an imaging diagnosis exam, using the principles and requirements that were developed based on the best practices and minimum legal requirements for radiology and imaging diagnosis services ${ }^{(4)}$.

The Apid Quality Management Principle (QMP-Apid) is one of the five principles that highlight quality planning and documentation requirements, risk management and patient safety, non-compliance management, patient complaints, adverse events and improvements; audits of the quality management system. Quality also stands out as a system of processes that progress in the continuous search for changes in the culture, performance and behavior of professionals towards concise, systemic and shared management practices ${ }^{(1-5)}$.

The practices developed in the environment of radiology and imaging diagnosis with constant advances in technology require qualified nursing in management, care and education. Nursing realizes the benefits of the accreditation certificate that guarantees quality, meeting established standards, helping people to identify services that provide safe assistance, in addition to creating self-improvement goals ${ }^{(6)}$.
Nursing influences and adds values to the practice in radiology and imaging diagnosis by incorporating assessment skills and initiatives of evidence-based practices, the Nurses'specialization in radiology and imaging is recognized by Resolution No. 570/2018, for professionals in higher education, and in Resolution No.609/2019, for middle-level professionals, from the Federal Nursing Council(-8).

Quality management as a principle of the accreditation program in imaging diagnosis is still recent, and the specific accreditation movement for imaging services by Apid has been gradually instituted as the accreditations occur, providing quality assessment as a tool management. No study has been found on the impacts on improvements and quality assurance in imaging services accredited by Apid, demonstrating that this is an issue that has not yet been studied ${ }^{(9)}$.

This attempt seeks to give visibility to nursing in compliance with the requirements of the program quality management principle, since ignorance may incur the invisibility of these professionals in radiology and imaging diagnosis.

Therefore, based on the professional experience of auditing, managing and caring patients in the RIDS, the question is: How does nursing contribute to the implementation of the requirements of the quality management principle of the accreditation program, promoting quality improvement?

\section{OBJECTIVE}

To know the contributions of nursing in the implementation of the principle of quality management of the accreditation program in imaging diagnosis.

\section{METHODS}

\section{Ethical aspects}

This study was carried out in accordance with Resolution 466/12 of the National Health Council and approved by the Research Ethics Committee on 06/27/2018. Data collection took place after explanations about the study and signing of the Informed Consent Form by the participants. The statements were identified with the letter $\mathrm{P}$ followed by the interview number, to guarantee anonymity.

\section{Type of study}

Exploratory study, with a qualitative approach, in the form of a single case study, of the common type, where it becomes possible to capture the circumstances and conditions of a daily situation, especially that of the outpatient service studied as the only unit of analysis of the phenomenon ${ }^{(10)}$.

\section{Study setting}

The study was carried out in an outpatient radiology and imaging diagnosis service, accredited by Apid in January 2018, located in Santa Catarina-SC. In this service, X-ray tests, Bone Densitometry, Ultrasonography, Computed Tomography, Magnetic Resonance, Prostate biopsies, and ultrasound-guided breasts were performed.

The multidisciplinary team service was composed of nurses, nursing technicians, radiology technicians, physicians and administrative professionals. 
All participants included in this study acted in the leadership of the sectors appointed by the service management and participated in the entire process for accreditation by Apid. Thus, the participants were the leading professionals of the quality teams, scheduling of exams, reception, nursing, medical, technicians/technologists in radiology and the direction of the service, these teams being represented respectively by a radiology technologist, administrator, people manager, nurse, physician, radiology technologist and administrator, totaling seven professionals and participants in this study.

The exclusion criteria were: being the leader of the outsourced service sector in the imaging service and not having followed the service preparation phase for accreditation.

\section{Data collection}

Interviews, direct observation and document analysis were used as data sources in this investigation ${ }^{(10)}$. Data collection was carried out at three different times during October 2018 and was guided by the criteria of the Consolidated Criteria for Reporting Qualitative Research (COREQ) checklist ${ }^{(11)}$.

At first, the data produced from the recorded and transcribed interviews were organized into texts named textual corpus by the lexical analysis software, which allowed the statistical analysis of these textual corpus to be performed by Computer Assisted Qualitative Data Analysis Software-Caqdas, R Interface pour les Multidimensionnelles Textes et Questionnaires- IraMuteq ${ }^{\circledast} 0.7$ Alpha $2^{(12)}$, used as a support for data analysis.

The second moment was direct observation, carried out on another day scheduled by the service directorate and elaborated after the application of the observational protocol, based on the twenty-seven requirements of the quality management principle, QMP-Apid, which dealt with quality planning and documentation; risk management and patient safety; non-compliance management; patient complaint; adverse events, improvements and audits of the quality management system, which led to the construction of a second textual corpus ${ }^{(4-12)}$.

In the third moment, a third visit to the service was made, with a similar schedule to the previous one, held in the quality sector. A checklist was applied where the variables (records of the checklist items) considered were the conformities and non-conformities related to the Program requirements, especially in the requirements of the QMP-Apid, recorded in the report resulting from the external audit in person at the service, which originated the accreditation certificate, which enabled knowledge about the result of the RIDS quality assessment, the scenario of this study.

IraMuteq $^{\circledR}$ software provides different types of textual data analysis by organizing the vocabulary distribution in a visually clear way, enabling the recovery of the context in which the words occur, meeting the functions provided for their use as support for data analysis of this case study ${ }^{(10-12)}$.

\section{Data analysis}

We used the Descending Hierarchical Classification (DHC), Reinert's method, as a way of organizing the data originated from the seven interviews, which through the crossing of text and word segments and textual statistics, they were grouped from the chi-square test $\left(\mathrm{chi}^{2}\right)$, representing the association of words, forming the lexical Units demonstrated and represented by the dendogram (Figure 1) ${ }^{(12)}$.

For the textual data-corpus, derived from the observational protocol, originated from direct observation, the Word Cloud (WC) was generated, another possibility offered by IraMuteq ${ }^{\circledR}$, which grouped and organized the words according to their frequency, shown in figure 2 , to complement the analysis ${ }^{(12)}$.

In the documentary analysis of primary source, the information contained in the external audit report of the service, referring to the fulfillment or not of the requirements of the QMP-Apid was contextualized in order to complement the apprehension of the object from the analysis of concrete data resulting from real practice, increasing the analysis of other data ${ }^{(13)}$.

For the description of the case, the evidence was triangulated, combining the results from different data sources: interview, direct observation and audit report. The analysis performed was based on the literature, QMP-Apid, and based on the critical analysis of the authors, based on the conclusion in the totality of the data ${ }^{(10)}$.

\section{RESULTS}

The corpus of the interviews had $74.97 \%$ of the text segments (TS), resulting in a dendogram with four different colors, provided by the DHC software (Figure 1) plus the words that stood out in the four lexical Units, named thematic Units and their relations, allowing the visualization of the words with greater frequency and higher values of $\mathrm{chi}^{2}$ in the Unit. All the selected words had a $p<0.001$ indicating a significant association, obtaining the context of the statistically significant words, enabling support for the qualitative analysis of these data ${ }^{(14)}$.

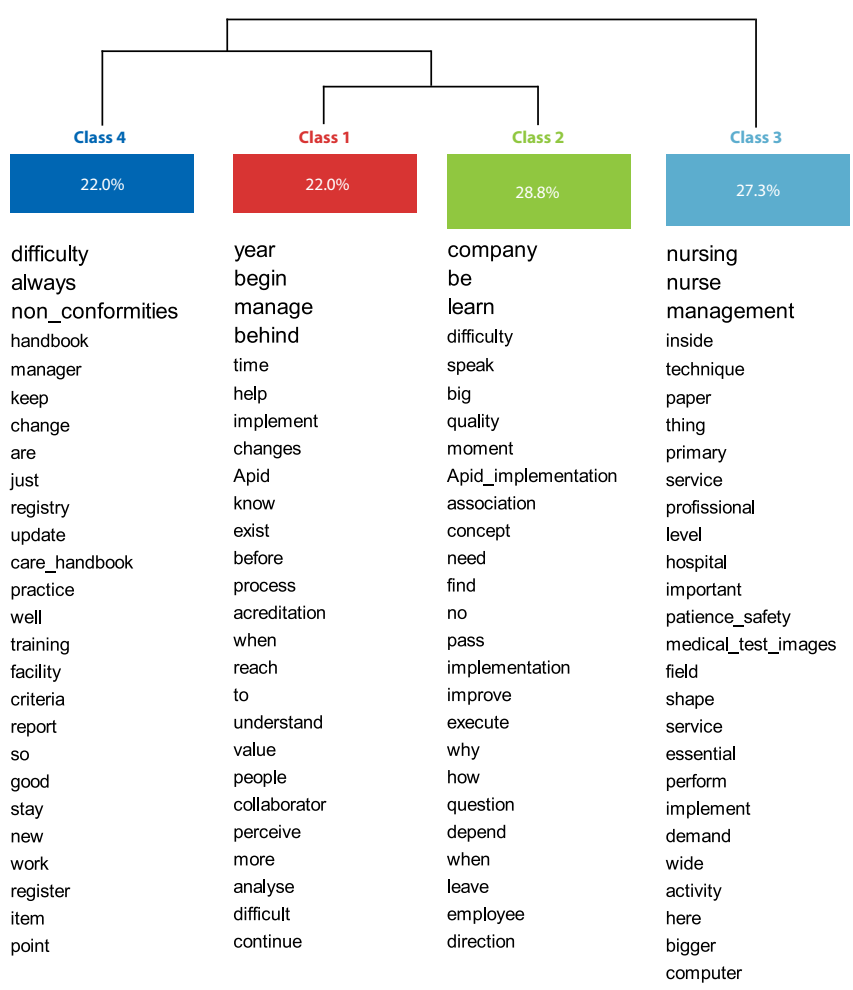

Figure 1- Dendogram with the different words associated with each of the Units, Rio de Janeiro, Rio de Janeiro, Brazil, 2019 
For Unit presentation, the corpus was divided into two sub corpus; from one of the sub corpus, Unit 4 originated, representing $22 \%$ of the corpus; showing a close relationship with Units 1 and 2, that is, presenting a common content. Unit 3 was generated from the other sub corpus, with $27.3 \%$ of representativeness and from the same sub corpus that originated Unit 4, Units 1 and 2 were obtained with $22 \%$ and $28.8 \%$ of the total corpus, respectively. The percentage referring to the content was the "occurrence of the word in the TS in the Units, in relation to its occurrence in the corpus" ${ }^{\prime \prime 12)}$.

Thematic Unit 1-In this Unit, the words: "process" (chi 9); "Year" (chi $\left.{ }^{2} 8\right)$, "collaborator" (chi $\left.{ }^{2} 7\right) ;$;Apid" (chi ${ }^{2} 7$ ) were highlighted and after understanding the association relationship between them and the context of their meanings, demonstrated in the following statements, the connection with "the accreditation process in imaging services" was noticed, with the name emerging from Unit.

Well, the Apid standard was perfect for us. We meet all the requirements [in terms of accreditation], and we try to improve more and more each day in a more efficient way. (P2)

I believe that we maintain all requirements from Apid. If we do an accreditation audit today, I believe we could do it again, but it is something that we must control all the time, always improving and it depends on people. (P1)

Thematic Unit 2- due to the combination of words and greater representation in the corpus, "quality" (chi $\left.{ }^{2} 14\right)$ "difficulty" (chi ${ }^{2}$ 13); "Company" (chi 12$)$; "How" (chi' 10$)$; aspects related to "the implementation of the program" were demonstrated as a result of the interviews below:

Well, the main difficulty to have Apid was the adherence of employees. Explain the importance that this has for the service, even for themselves. So, I see that our main difficulty was adherence and showing the importance of why we want quality, continuous improvement, making everyone adhere to the process, because it's no use if the management and supervisors know, if the employees don't adhere. Because the service depends on them. (P2)

Apid is the first step, we're aware of the importance of continuous improvement. It certainly brings a change bag, an improvement on us. We created the awareness that we're looking to improve that control, that tool [...] (P4)

One of the main things that we noticed was what Apid brought, despite all the difficulties of implementation, the fact that we started to have the record of everything, it gave us an opportunity with this record to make a statistic, an evaluation of the problems that are happening, their incidence and we are able to anticipate and solve it before they occur. (P3)

Thematic Unit 3-The combination of the words nursing (chi ${ }^{2}$ 18); imaging service (chi $\left.{ }^{2} 12\right)$; form (chi $\left.{ }^{2} 11\right)$; management (chi ${ }^{2}$ 8), proved to be quite expressive, referring to "the role of nursing in imaging services and patient safety", according to the statements below:

[...] the nursing activity within the company is essential in our company. It's not only important or necessary, it's essential. Because we have processes, controlled medication control, give the contrast, deal directly with the patient, give an explanation to the patient, the physicians do not do that, if they did, "cool", but they stop at their practice, making the report. Management of non-conformities, nursing and staff training. How can I convince the physician to train the staff? It's so hard. (P1)

[...] nursing embraces several processes and has a great knowledge of this segment, in terms of care, safety, choosing the best materials to avoid contamination, sterilization, issues of lead clothing, medication, contrasts, which medication is most appropriate. (P7)

[...] nursing in risk management and patient safety was very important in terms of manuals that helped a lot. Nursing brought knowledge to us, which we didn't have, in the matter of manuals, for me mainly, I followed some documents that were made and patient safety, we made these manuals together. (P6)

Thematic Unit 4-The words "record" (chi 8); "Non-conformities" (chi' 8); "Difficult" (chi 7); "Manual" (chi $\left.{ }^{2} 6\right)$ portrayed "The management of non-conformities in imaging services", showing a close relationship with Units 1 and 2, as shown in figure 1. Nonconformities originated during the evaluation of the requirements of the Apid Standard in the process of accreditation of imaging services, explaining the differentiated link among the three Units.

\begin{abstract}
Another thing that helps us a lot in improvement is a non-conformity management tool, which today we call "Help 10" of quality, all items, the entire company, all employees of the company were and are daily oriented to what and how to do, report any problems. Which category fits this problem? You go there in the call, in the system, in that category, write the problem, which then will be analyzed as a non-compliance by someone if there's a need for treatment. (P1)
\end{abstract}

After the results of the interviews, it was understood as important to verify the frequency with which the words appeared in direct observation so that the two results could be corroborated. Therefore, for the organization of the data and analysis of the textual corpus originated from the application of the observational protocol of direct observation, WC was chosen (Figure 2 ), considered the simplest lexical analysis of IraMuteq ${ }^{\circledR}$, which allowed the rapid identification of key words from the corpus, organizing them graphically according to their frequency ${ }^{(12)}$.

With a use of $78.57 \%$ of the TS, the words highlighted in larger size were the most used in the formation of the "cloud", following the order given by the software named by active forms, being: "risk" (18 times), patient (10 times), team (8 times), exam (8 times), quality (8 times), care (6 times), nurse (6 times), leadership (6 times), improvement ( 6 times), record ( 6 times), shown in Figure 2.

As a result of the third data source, resulting from the checklist applied in the external audit report (ER), originated from the service evaluation process, it was found that the service had five non-conformities out of a total of 197 requirements of all the principles of the Program. However, in the QMP-Apid relevant to this study, there was only one unmet requirement. In the ER report, the QMP-Apid, formed by 27 requirements (6.1.1- 6.4.4), showed only one unmet requirement that generated the nonconformity (NC). The evidence was the absence of minimum elements required by the Apid requirement in the service documents, 
with the mentioned document being an informed consent form for an examination with sedation, requirement 6.1.4. The lead auditor of the external team that audited the service reported $97.5 \%$ of requirements met.

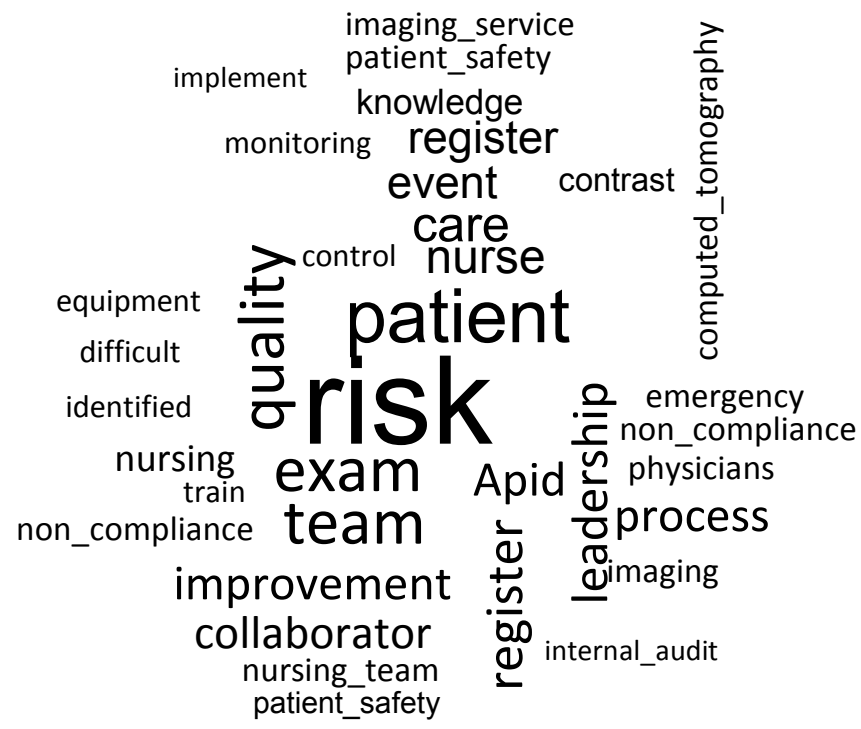

Note: *Accreditation Program in Imaging Diagnosis

Figure 2-Word cloud constructed with words extracted from direct observation based on the requirements of Apid* quality management principle, Rio de Janeiro, Rio de Janeiro, Brazil, 2019

The results of the different data sources demonstrated a complementarity between them, since the study was more concise throughout the development of the different techniques. The WC evidenced words that were part of the Units presented by the dendrogram and the data originating from the checklist, which strengthened the other data, since it demonstrated the result of the evaluation of the quality of service, consistent with the crossing of texts and words from other techniques ${ }^{(10)}$.

\section{DISCUSSION}

Accreditation has gained worldwide attention as an effective tool for assessing quality and management. The accreditation process at the RIDS as a result of this study represented by the first thematic Unit, was seen as a way to improve the quality of images, reports, mitigate clinical risks related to patient care, professionals safety, companions, visitors and sustainability of the service on the market ${ }^{(4-6)}$.

In developing countries, accreditation is increasingly being used as a regulatory tool by governments to guarantee quality of care. We emphasize Lebanon as the first country in the eastern Mediterranean to develop and implement accreditation standards in a study carried out with a total of 59 nurses, confirming that these professionals are the ones who most perceive the improvement in quality and recognize accreditation as a good tool for improving quality of care ${ }^{(5-6)}$. Nursing, as the team that interacts for the longest time with the patient, perceives their expectations of care better, recognizing the evolution and involution of quality in the care provided. The representativeness identified in figure
2 evidenced the importance of the role of nurses and their team in the entire process of accreditation of the RIDS.

The health market favorable position for RIDS accreditation is increasingly consolidated and nursing recognizes its gains in the execution of strategic quality planning, education, training and teamwork, which through leadership and commitment, points to team involvement as result of quality ${ }^{(5,15)}$.

Implementing Apid has become a goal of the service employees evidenced in the formation of the thematic Unit in the graphic appearance in the WC, confirmed by the checklist, incurring in knowing the existing culture in the service, attitudes, values, relationships, skills, norms, standards of behavior for the elaboration of strategies that promote improvements aiming at the construction of an environment without punishment, without guilt, where risks are recognized and registered; unconformities; events; adverse reactions to be monitored and treated to mitigate recurrence ${ }^{(4,16)}$.

The documented records of risks, notification of events and adverse reactions to medications are essential for this process to be implemented referring to recognition and prevention of new occurrences. For this, nurses, as team leaders, need the skill and attitude to deal with the "organizational culture" versus "culture of concealment", which often guides the behavior of professionals, in contrast to the intended "safety culture" that among others have determinants in interprofessional relationships and local circumstances ${ }^{(17-18)}$. They are also a formulator of processes, documents, foresee and provide material resources, medications, contrast media, psychotropic drugs for sedation, participate in institutional policies and guidelines, among other duties ${ }^{(19)}$.

For the execution of possible strategies designed to achieve this goal, the interconnection of sectors and their collaborators is assumed through teams, given the complexity of the system in which the processes are interrelated in such a way that any component can interfere in the service result ${ }^{(20)}$. As a team in the imaging service, nursing moves through different sectors and participates in several processes for having knowledge of the particularities of the different methods of imaging exams, carrying out actions that collaborate to generate quality images, managing the risks to avoid damage to the patient and act in all phases of the exams; before, during and after ${ }^{(21)}$.

The accreditation of RIDS by Apid consists of issuing a certificate after face-to-face evaluation by a trained multidisciplinary team named external audit, valid for one year. Thus, in the following year, the audit takes place through a documentary evaluation, and in the third year, it returns to the face-to-face evaluation. Before all audits, the service must submit the images and reports for the evaluation of radiologists and meet the minimum requirements designated by BSR/Apid, as an accrediting entity contained in the accreditation program(1).

At the end of the audits, an external audit report is generated with a description of the non-conformities found, if there is. Non-conformities must be dealt with within a period of up to sixty days after receiving the report by the service. Only after this fulfillment the service could be approved or disapproved ${ }^{(4)}$.

According to the testimonies of the participants, there was an understanding that people's adherence to the accreditation process through continuous improvement was essential. However, changes in attitudes towards work practices in the perception of 
the new reality of the market and the patient, in the quest to add value to the service, were necessary to achieve the objectives set for obtaining quality. These changes are not always perceived as positive by the board, professionals and collaborators, causing the resistance of the people involved to compromise the capacity for beneficial changes to the service ${ }^{(22)}$.

Therefore, the relationship and the exchange of knowledge between the imaging service teams favor changes. Nursing interacts with the other teams in the imaging service, managing care through collaboration and communication, holding its own knowledge of the particularities of the different methods of imaging exams and executing actions that involve patient safety, searching for risk factors for extravasation of contrast media, development of adverse reactions to contrast, emergency response, care with radiation with the magnetic field; techniques for patient positioning on the equipment, assistance with various biopsy techniques and conditioning of biological samples. The team leading nurse is a formulator of processes, documents, foresees and provides material resources, medications, contrast media, psychotropic drugs for sedation, participates in institutional policies and guidelines, among other duties ${ }^{(19,21)}$.

Nursing, cited as essential in the imaging service, was associated with risk management that was linked to the desired "safety culture", assuming learning from failures to prevent and mitigate the risks of new incidents that may cause damage related to the patient care. Thus, the requirements of Apid, which make up the QMP, advocated the commitment of the service to the dissemination of concepts about risks, their identification, analysis, treatment and monitoring to promote the adoption of safe professional practices, and notification through records was essential ${ }^{(1,23)}$.

Strengthening the speeches of the participants and the results already presented, the components of Apid quality management were shown in Figure 2, highlighting the word "risk" that incorporated into the quality, patient safety and related to the recording of adverse events, carrying out internal audits, non-conformities understood as opportunities for improvement, integrated with the quality management principle of the accreditation program, resulted in quality certification ${ }^{(24)}$.

Some patients required sedation to perform exams, mainly magnetic resonance, where psychotropic drugs were administered by the anesthetist and monitored by nursing before, during and after the exam. In addition, it was through risk management that nursing helped in the decision making of the radiologist, in the use of the contrast medium that can be harmful to the patient, depending on the risk factors involved and investigated by the nursing team ${ }^{(25-26)}$.

The representativeness identified in Figure 2 suggested the participants' knowledge of the QMP-Apid, indicating the importance of the role of nurses and their team in the entire RIDS accreditation process. The other words cited, close to each other, consolidated the participation and understanding of employees on the relevance of the records, since the quality management was also done through records of complaints, failures and errors that were registered as non-compliance (NC), which should not be considered negatively, but as an opportunity for improvement, learning and method of updating processes, but it is not consistent with reality ${ }^{(27)}$.
Every management system needs processes to deal with and manage NCs, another thematic Unit of the study, which can count on computerized or manual systems, for records and subsequent management. All sectors must register and adjust their NCs, as the success or failure of the accreditation process will depend on it, that is, if any QMP-Apid requirements are not in compliance, an investigation of the root cause (reason) begins so that an action is proposed and executed (corrective action). It is necessary, after the implementation of the action, to verify its effectiveness, that is, to verify if the action solved the problem and did not happen again ${ }^{(4,28)}$.

The evaluation of the service documents was carried out randomly and by sampling, and this NC demonstrated that the methodologies for preparing, approving, identifying, distributing and keeping the documents deviated from the control standards that guaranteed the analysis, issuance, alteration, disapproval, in order to avoid the use of obsolete and invalid documents in the service ${ }^{(4,29)}$.

After the checklist in Apid report, originated from ER, where non-conformities, observations (potential non-conformities) and opportunities for improvement (contribution of auditors to strengthen the requirement that were weakly met) were described, the educational nature of the report to be considered as a permanent education activity and never as an interpretation of supervision ${ }^{(30)}$.

Through the evidenced data, the set of NC reflected the quality of the RIDS, and as the other requirements of the QMP-Apid were all met, it was configured that new arrangements in the team, commitment to innovation of the accreditation program and investment in the capacity of analysis of the actions taken, can cause changes in the desired "quality and safety culture"(31).

\section{Limitations of the study}

The limitations were centered on the impossibility of inference from the study to other contexts, and it is not possible to carry out a theoretical replication, as it is a single case study. The participation of nursing in the context of the quality management of the accreditation program of the radiology and imaging diagnosis service presents specificities of this specialty, but not in its entirety.

\section{Contributions to nursing, health or public policy}

Nursing in radiology and imaging is a specialty that is not a focus in nursing schools, and more recent nurses may be unaware of the role of nurses in this care specialty. It is intended to bring the notability of the nursing team in imaging services, under the care and management perspective, in addition to the dissemination of knowledge produced in this care specialty, which is still not very widespread in nursing.

\section{FINAL CONSIDERATIONS}

Nursing contributed to the implementation of the Quality Management Principle of the Accreditation Program in Imaging Diagnosis through risk management and patient safety when investigating risk factors with the patient to identify vulnerabilities that could cause harm arising from the administration of contrast 
means or other medications used in various tests; when it notifies and records adverse events and reactions to understand the possible failure that has occurred and to implement corrective and preventive actions to minimize future occurrences.

Even when interacting with the other teams in the imaging service, it provides better management of care through multidisciplinary, collaboration and communication, providing a greater contribution to the implementation of quality management requirements. Its contribution to the implementation of the Quality Management Principle of the Accreditation Program in Imaging Diagnosis in the imaging service was also highlighted when the result of the external audit demonstrated a single requirement among the 27 requirements of the quality management principle, which was not met.

With the increase in the demand for care and technological advances in radiology and imaging diagnosis services, the participation of a qualified nursing will be a differential for accredited imaging services and for those who aspire to accreditation.

\section{FUNDING}

Fundação de Amparo a Pesquisa do Estado do Rio de Janeiro- FAPERJ.

\section{REFERENCES}

1. Colégio Brasileiro de Radiologia e Diagnóstico por Imagem-CBR. Norma do Programa de acreditação em diagnóstico por imagem-Padi; versão 3.0, São Paulo, 2017.

2. Aquino AT, Silva JL, Melo RM, Silva MM. Organizational change in quality management aspects: a quantitative proposal for classification. Production, 2017;27:e20162165. https://doi.org/10.1590/0103-6513.216516

3. Cantiello J, Kitsantas $\mathrm{P}$, Moncada S, Abdul S. The evolution of quality improvement in healthcare: patient-centered care and health information technology applications. J Hosp Adm. 2016;5(2):62-8. https://doi.org/10.5430/jha.v5n2p62

4. Colégio Brasileiro de Radiologia e Diagnóstico por Imagem-CBR. Norma do Programa de acreditação em diagnóstico por imagem-Padi; versão 4.0, São Paulo, 2019.

5. Reisi N, Raeissi P, Sokhanvar M, Kakemam E. The impacto of accreditation on nurses perceptions of quality of care in Iran and its barrierand facilitators. 2019;34:e230-e240. https://doi.org/10.1002/hpm.2642

6. Balghat S. Accreditation and importance of quality assurance in health industry. Conference: Accreditation And Importance Of Quality Assurance In Health Industry [Internet]. India; 2018[cited 2019 Jun 08]. https://www.researchgate.net/publication/323676187

7. Conselho Federal de Enfermagem (COFEN). Resolução n 570/2018. Atualiza, no âmbito do Sistema Cofen/ Conselhos Regionais de Enfermagem, os procedimentos para registro de títulos de pós graduação lato e stricto sensu concedido a enfermeiros e lista de especialidades[Internet]. 2018 [cited 2019 Jul 08]. Available from: http://www.portalcofen.gov.br/pdf

8. Conselho Federal de Enfermagem-COFEN, Resolução n 609/2019. Atualiza, no âmbito do Sistema Cofen /Conselhos Regionais de Enfermagem, os procedimentos para registro de especialização técnica de nível médio em Enfermagem concedida aos Técnicos de Enfermagem e aos Auxiliares de Enfermagem[Internet]. 2019 [cited 2019 Jun 08]. Available from: http://www.portalcofen.gov.br/pdf

9. Lare W, Puchnick A, Bancovsky E, Bettini PR, Vedolin LM, Chammas C. Reproducibility of a quantitative system for assessing the quality of diagnostic ultrasound. Radiol Bras. 2018;51(3):172-7. https://doi.org/10.1590/0100-3984.2017.0021

10. Yin RK. Estudo de caso: planejamento e métodos. 5ed. Porto Alegre (RS): Bookman; 2015.

11. Portugal AC, Santos CHS, Campos FM, Leoni L, França RR, Silva VS, et al. Artigo científico na área da saúde: diretrizes para sua elaboração e avaliação. Rev Ciênc Méd Biol. 2018;17(2):265-71. https://doi.org/10.9771/cmbio.v17i2.25135

12. Camargo BV, Justo AM. Tutorial para uso do software de análise textual IRAMUTEQ. Universidade Federal de Santa Catarina[Internet]. 2013[cited 2019 Feb 22]. Available from: http://www.iramuteq.org/documentation/fichiers/tutoriek-en-portugais.pdf

13. Cechinel A, Fontana SAP, Della KGP, Pereira AS, Prado SS. Estudo/análise documental: uma revisão teórica e metodológica. Criar Educação, PPGE - UNESC. 2016;5(1):279-52. https://doi.org/10.18616/ce.v5i1.2446

14. Souza MAR, Wall ML, Thuler ACMC, Lowen IMV, Peres AM. The use of IRAMUTEQ software for data analysis in qualitative research. Rev Esc Enferm USP. 2018;52:e03353. https://doi.org/10.1590/s1980-220x2017015003353

15. Chander M. Quality program in radiology: persue ou perish. Indian J Radiol Imaging. 2017;27(1):1-3. https://doi.org/10.4103/ijri.IJRI 99 17

16. Batalha EMSS, Melleiro MM. Patient safety culture in a teaching hospital: diferences in perception existing in the diferente scenarios of this institution. Texto Contexto Enferm. 2015;24(2):432-41. https://doi.org/10.590/0104-07072015000192014

17. Góis RMO, Santos AAA, Reis JB, Freitas JEF, Santos REC. Liderança em enfermagem: desafio nas práticas gerenciais a partir de um estudo bibliográfico. Ciênc Biol Saúde[Internet]. 2015[cited 2020 Mar 13];3(1):73-86. Available from: https://periodicos.set.edu.br/index.php/ cadernobiologicas/article/view/2429

18. Amestoy SC, Trindade LL, Silva GTR, Santos BP, Reis VRSS, Ferreira VB. Leadership in nursing: from teaching to practice in a hospital environment. Esc Anna Nery. 2017;21(4):1-6. https://doi.org/10.1590/2177-9465-EAN-2016-0276

19. Wempe EP, Role of the nurse practitioner in delivering quality care in the radiology and imaging setting. J Radiol Nurs. 2020;39(3):249-50. https://doi.org/10.1016/j.jradnu.2020.06.006 
20. Pereira AG, Vergara LGL, Merino EAD, Wagner A. Soluções no serviço de radiologia no âmbito da gestão: uma revisão de literatura. Radiol Bras. 2015;48(5):298-304. https://doi.org/10.1590/0100-3984.2014.0065

21. Vlach RJ, Radiology nursing specialty orientation. J Radiol Nurs. 2018;37(2):112-8 https://doi.org/10.1016/j.jradnu.2017.12.007

22. Marques AL, Borges R, Reis IC. Organizational change and work satisfaction: a study of civil servants in Minas Gerais State. Rev Adm Pública. 2016;50(1):41-58. https://doi.org/10.590/0034-7612131034

23. Borges TAC, Sá RC, Neves MGC. Nursing care planning: proposal for implementation of an administrative-care instrument. Com Ciênc Saúde[Internet]. 2017[cited 2020 Feb 22];28(3/4):413-8. Available from: http://bvsms.saude.gov.br/bvs/periodicos/ccs_artigos/ v28_3planejamento_assistencia_enfermagem.pdf

24. Oliveira JLC, Gabriel CS, Fertonani HP, Matsuda LM. Management changes resulting from hospital accreditation. Rev Latino-Am. Enfermagem. 2017;25:e2851. https://doi.org/10.1590/1518-8345.1394.2851

25. Acauan LV, Rodrigues MCS. Perceptions of the nursing staff regarding the safety of elderly patients in the cardiac computed tomography. Texto Contexto Enferm. 2014;23(2):338-46. https://doi.org/10.1590/0104-07072014003860012

26. Rodrigues JT, Oliveira C, Ferreira AP. Ventilação a jato de alta frequência: uma nova abordagem no manejo da anestesia para ressonância magnética em cardiologia pediátrica, série de casos. Rev Bras Anestesiol. 2019;69(6):626-30. https://doi.org/10.1016/j.bjan.2019.08.007

27. Nunes LCPC, Fontes MO, Oliveira MAS. Identificação das principais não conformidade nas auditorias dos hospitais de Salvador realizadas pelo sistema nacional de auditoria em 2013. Rev Eletrôn Atualiza Saúde [Internet]. 2015[cited 2019 Sep 10];2(2):44-50. Available from: http://atualizarevista.com.br/article/identificacao-das-principais-nao-conformidades-nas-auditorias-dos-hospitais-de-salvador-realizadaspelo-sistema-nacional-de-auditoria-em-2013-v-2-n-2.pdf

28. Hebert R, Moraes SRL, Koller FJ. Non-Conformities that Hinder Health Institution to be Accredited: integrative review. AJBSR 2020;7(5):42833. https://doi.org/10.34297/AJBSR.2020.07.001192

29. Agência Nacional de Vigilância Sanitária (Anvisa). Gestão de riscos e investigação de eventos adversos relacionados à assistência à saúde. Brasília: Anvisa; 2017.

30. Schiesari LMC. External evaluation of hospital organizations in Brazil: could things be done differently? Ciênc Saúde Colet. 2014;19(10):422934. https://doi.org/10.1590/1413-812320141910.21642013

31. Wegner W, Silva SC, Kantorski JC, Predebon CM, Sanches MO, Pedro ENR. Education for culture of patient safety: implications to professional training. Esc Anna Nery 2016;20(3):e20160068. https://doi.org/10.5935/1414-8145.20160068 